\title{
6: 46386637-46392695
}

National Cancer Institute

\section{Source}

National Cancer Institute. 6: 46386637-46392695. NCI Thesaurus. Code C41888.

Physical location of CCR5_Gene 